\title{
SOME NEW PACHPATTE TYPE INEQUALITIES ON TIME SCALES AND THEIR APPLICATIONS
}

\section{LIWEI DU AND RUN XU}

Abstract. The aim of this paper is to establish some new Pachpatte type inequalities on time scales, which provide explicit bounds on unknown functions. Our results extend some known Pachpatte inequalities on times scales, unify and extend some continuous inequalities and their corresponding discrete analogues. The inequalities given here can be used as tools in the qualitative theory of certain differential equations and dynamic equations. Some examples are given in the end of this paper.

Mathematics subject classification (2010): 34C10.

Keywords and phrases: Time scales, Pachpatte inequality, dynamic equation, integral inequalities.

\section{REFERENCES}

[1] W. N. LI, Some Pachpatte type inequalities on time scales, Computers and Mathematics with Applications 57 (2009), 275-282.

[2] S. Hilger, Analysis on measure chains-a unified approach to continuous and discrete calculus, $\mathrm{Re}-$ sults in Mathematics 18, 1-2 (1990), 18-56.

[3] W. N. LI, Bounds for certain new integral inequalities on time scales, Advances in Difference Equations, Volume 2009, Article ID 484185, 16 pages, doi:10.1155/2009/484185.

[4] M. Bohner And A. Peterson, Dynamic equations on time scales: An Introduction with Applications, Birkhäuser, Boston, Mass, USA, 2001.

[5] F. Wong, C. C. YeH, C. H. Hong, Gronwall inequalities on time scales, Math. Inequal. Appl. 9 (2006), 75-86.

[6] D. B. PACHPATTE, Explicit estimates on integral inequalities with time scales, Journal of Inequalities in Pure Applied Mathematics 7, 4 (2006), article 143, pp. 8 pages.

[7] Wei NiAn Li, Some new dynamic inequalities on time scales, Journal of Mathematical Analysis and Applications 319, 2 (2006), 802-814.

[8] Wei Nian Li and Weihong Sheng, Some Nonlinear Integral Inequalities on Time Scales, Journal of Inequalities and Applications, Vol. 2007, Article ID 70465, 15 pages. doi:10.1155/2007/70465.

[9] W. N. LI, Some Pachpatte type inequalities on Time Scales, Computers and Mathematics with Applications 57 (2009), 275-282.

[10] W. N. LI, Some delay integral inequalities on time scales, Computers and Mathematics with Applications 59 (2010), 1929-1936, 2010. doi:10.1016/j.camwa.2009.11.006

[11] E. Akin-Bohner, M. Bohner, And F. Akin, Pachpatte inequalities on time scales, Journal of Inequalities in Pure Applied Mathematics 6, 1 (2005), article 6, pp. 23 pages.

[12] B. G. PAChPATte, Bounds on certain integral inequalities, J. Inequal. Pure Appl. Math. 3 (2002), Article 47

[13] B. G. PACHPATte, Inequalities for Differential and Integral Equations, Academic Press, New York, 1998.

[14] B. G. Pachpatte, Inequalities for Finite Difference Equations, Marcel Dekker Inc., New York, 2002. 